\title{
Bioaccumulation of chromium by Fusarium oxysporum
}

\author{
Saba Khurshid ${ }^{\mathrm{a}}$, Amna Shoaib ${ }^{\mathrm{a}, *}$, Arshad Javaid $^{\mathrm{a}}$, Kamran Abid ${ }^{\mathrm{b}}$ \\ ${ }^{a}$ Institute of Agricultural Sciences, University of the Punjab, Lahore, Pakistan \\ b Department of Electrical Engineering, University of the Punjab, Lahore, Pakistan
}

*Corresponding author, e-mail: aamnaa29@yahoo.com, amna.iags@pu.edu.pk

Received 5 Dec 2014

Accepted 11 Mar 2016

\begin{abstract}
We investigated the impact of both hexavalent and trivalent chromium on mycelial growth and metal accumulation in the wilt pathogen of tomato (Fusarium oxysporum f. sp. lycopersici). Experiments were conducted in liquid growth medium amended with 19 concentrations of either $\mathrm{Cr}$ (III) or $\mathrm{Cr}$ (VI). Metal-amended medium was inoculated with the pathogen and incubated for 15 days at $25 \pm 3{ }^{\circ} \mathrm{C}, 50 \mathrm{rpm}$, and at pH 5 . Generally, the fungal dry biomass was significantly inhibited by $14-64 \%$ and $30-95 \%$ with increase in concentrations (5-350 ppm) of Cr(III) and $\mathrm{Cr}(\mathrm{VI})$, respectively. The fungus was unable to grow at metal concentrations higher than $400 \mathrm{ppm}$. The metal accumulation by the fungus decreased with an increase in metal concentration. The fungal biomass exhibited the greater accumulation capacity $(0.01-2.6 \mathrm{mg} / \mathrm{g})$ for $\mathrm{Cr}(\mathrm{VI})$ than that of $\mathrm{Cr}$ (III) $(0.01-1.86 \mathrm{mg} / \mathrm{g})$. The bioaccumulation factor of the fungus for both oxidation states of $\mathrm{Cr}$ ranged between 0.7 and 0.9.
\end{abstract}

KEYWORDS: heavy metal, wilt pathogen, Solanum lycopersicum, tomato

\section{INTRODUCTION}

Heavy metal pollution of water and soil is wellknown dilemma of the current century. Among toxic heavy metals, chromium (Cr) is an important industrial metal utilized widely in metallurgy, refectory, plating and tannery industries, wood preservation, and pigment manufacturing ${ }^{1,2}$. Although it exists in many oxidation states, $\mathrm{Cr}(\mathrm{III})$ and $\mathrm{Cr}(\mathrm{VI})$ are the most stable forms in the environment ${ }^{3}$. $\mathrm{Cr}$ (III) mainly exists as hydroxides, oxides, or sulphates, and a small amount is vital for men, animals, and microorganisms. However, its requirement for plants is debatable ${ }^{4,5}$. The divalent oxyanions of $\mathrm{Cr}(\mathrm{VI})$ are 100-1000 times more toxic, more soluble in water, and more motile and strong oxidizing agent than $\operatorname{Cr}(\mathrm{III})^{6,7}$; hence it has been declared lethal for all living organisms ${ }^{8}$. Thus it is imperative to consider the significance of $\mathrm{Cr}$ for soil biota as one gram of soil may comprise $0.005-3 \mathrm{mg}$ of $\mathrm{Cr}^{9}$.

In soil, reaction of microorganism varies and heavy metal contamination can shift microbial populations $^{10,11}$. Fungi are more resistant to metal toxicity due to physiological adaptation, while exist as dominant community in metalliferous soil. Nevertheless, under the influence of adverse environmental condition, fungi can survive due to their innate ability to take up the pollutants as nutrients through absorption or accumulation ${ }^{12}$. In adsorption, heavy metals are deposited in the mosaic structure of the fungal wall that provides excellent metal binding properties ${ }^{13}$. Metals, when accumulated in the cytoplasm of the fungal cells, damage the majority of enzymes and proteins by two principal mechanisms. In an extracellular mechanism, metals enter in cell and bind to ligands (e.g., citrate, oxalate) or cell wall components (chitin, glucan) ${ }^{14}$. The mechanism involves intracellular detoxification through association of metal to intracellular compounds such as metallothionein and glutathione ( $\mathrm{GSH}$, a small sulphur containing molecule) ${ }^{15}$.

It has been documented that various heavy metals in the medium bestowed differential responses to various fungal species and isolates of the same genus ${ }^{16}$. So far, soil is a reservoir of both saprophytic and pathogenic mycoflora. Majority of the reports are available on interaction of heavy metals with saprophytic fungi ${ }^{17}$. However, the interaction of heavy metals (particularly $\mathrm{Cr}$ ) with plant pathogenic fungi is not well known ${ }^{18}$.

F. oxysporum is a highly destructive soil-borne ascomycetous fungus that infects all the agricultural and horticultural crops globally in warmer areas ${ }^{19}$. In comparison to other soil-borne fungal pathogens, the wilt pathogens have a more specialized host range (classified as forma specialis) and are adapted to colonize the vascular system of their hosts. Strains that cause wilt disease in tomatoes are classified as f. sp. lycopersici (FOL). Seedlings infected by FOL show yellowing of lower leaves, 
often only on one side of the plant succeeded by reduced growth and eventually death of the entire plant $^{20}$.

It is hypothesized that when metal laden water is used to irrigate the agricultural fields, these heavy metals interact with phytopathogens present in the respective area. Those microbes may exhibit over or under activity in terms of pathogenicity and finally integrate into the food chain. The toxicology of $F$ oxysporum has been established due to its ability to produce a wide range toxins in plants such as moniliformin, fusaric acids, fumonisins, and trichothecenes ${ }^{21}$. These toxins may become part of the food chain through accumulating in the end product $^{22}$. F. oxysporum f. sp. lycopersici has the ability to degrade humic substances with subsequent increase in metal solubilization and bioaccessibility to tomato plant ${ }^{23}$. Increase in disease severity caused by $F$. oxysporum f. sp. radicis lycopersici increases with an increase in lead uptake by the tomato plant ${ }^{24}$. Thus under the combined stress of the heavy metal and fungal pathogen, the plant could suffer more due to the synergistic action of both stresses. So the presently planned study aimed to investigate the impact of $\mathrm{Cr}$ (III) and $\mathrm{Cr}(\mathrm{VI})$ on growth, metal accumulation, metal uptake capacity, efficiency, and bioaccumulation factor (BF) in wilt pathogen of tomato, i.e., F. oxysporum f. sp. lycopersici under laboratory conditions. It is assumed that $F$. oxysporum f. sp. lycopersici being a robust pathogen can tolerate high concentration of $\mathrm{Cr}$ and later can promote metal uptake by the plant.

\section{MATERIALS AND METHODS}

F. oxysporum f. sp. lycopersici was aseptically isolated from roots of tomato plants suffering from wilt disease. The fungus was subcultured and maintained on $2 \%$ malt extract agar medium and identified on the basis of micrometry and morphological characters $^{21}$.

Stock solutions of $\mathrm{Cr}$ (III) and $\mathrm{Cr}(\mathrm{VI})$ were prepared by dissolving each $7.69 \mathrm{~g}$ chromium nitrate, $\mathrm{Cr}\left(\mathrm{NO}_{3}\right)_{3} \cdot 9 \mathrm{H}_{2} \mathrm{O}$, and $2.82 \mathrm{~g}$ potassium dichromate, $\mathrm{K}_{2} \mathrm{Cr}_{2} \mathrm{O}_{7}$ (Merk, Germany) in $1000 \mathrm{ml}$ distilled water. Further dilutions of $5,10,20, \ldots, 100,150$, $200, \ldots, 500 \mathrm{ppm}$ were prepared by adding the appropriate quantity of sterilized distilled water.

Experiments were conducted in $250 \mathrm{ml}$ flask filled with $2 \%$ malt extract broth $(100 \mathrm{ml})$ amended with 19 different concentrations of each of $\mathrm{Cr}$ (III) and $\mathrm{Cr}(\mathrm{VI})$ ranging from $0,5,10,20, \ldots, 100$, $150,200, \ldots, 500$ ppm. Flasks were inoculated with $2 \mathrm{~mm}$ disc of $F$. oxysporum f. sp. lycopersici and incubated at $25 \pm 3^{\circ} \mathrm{C}, 50 \mathrm{rpm}$, and for 15 days. Treatments with the fungal inoculum but without addition of $\mathrm{Cr}(\mathrm{III})$ or $\mathrm{Cr}(\mathrm{VI})$ solutions were the control. Each treatment was done in triplicate and the experiment was performed using completely randomized design. After the incubation period, the biomass of fungus was separated from the culture broth by filtration and subjected to successive washings with double distilled deionized water to remove the culture broth. Dry weights of the fungus were recorded on pre-weighted filter paper.

Remaining $\mathrm{Cr}$ in fungal biomass as well as in culture broth was analysed by atomic adsorption spectrophotometry. The sample was digested using 3:1 mixture of concentrated $\mathrm{HNO}_{3}(69-70 \%)$ under reflux at a temperature of $240^{\circ} \mathrm{C}$ for $2 \mathrm{~h} 30 \mathrm{~min}$. The digests were filtered through Whatman No. 1 filter paper and the filtrate was diluted up to $30 \mathrm{ml}$ and subjected to analysis of $\mathrm{Cr}$ on Z-5000 Polarized Zeeman atomic adsorption spectrophotometer. The amount of chromium accumulated by fungal biomass and the efficiency of biomass were calculated as $q=\left(C_{\mathrm{i}}-C_{\mathrm{f}}\right) V / m$ and $E=\left(C_{\mathrm{i}}-C_{\mathrm{f}}\right) / C_{\mathrm{i}}$, respectively, where $C_{\mathrm{i}}$ and $C_{\mathrm{f}}$ are the initial and final concentrations of the metallic ion, $m$ is the fungal mass in the reaction mixture, and $V$ is the volume of reaction mixture.

The bioaccumulation factor, $\mathrm{BF}$, was calculated as $\mathrm{BF}=C_{\mathrm{m}} / C_{\mathrm{s}}$, where $C_{\mathrm{m}}$ is the metal concentration in fungus and $C_{\mathrm{s}}$ is the metal concentration added in the growth medium.

All the data were analysed through ANOVA technique and the means were compared using Tukey's test $(p \leqslant 0.05)$ to separate mean differences.

\section{RESULTS}

ANOVA for the data recorded on the effect of nineteen concentrations (5-500 ppm) each of $\mathrm{Cr}(\mathrm{III})$ and $\mathrm{Cr}(\mathrm{VI})$ on biomass production of $F$. oxysporum f. sp. lycopersici is pooled in Table 1. According to ANOVA, the effect of metal oxidation states (MOS)

Table 1 Effect of $\mathrm{Cr}$ (III) and $\mathrm{Cr}$ (VI) on the biomass of F. oxysporum f. sp. lycopersici.

\begin{tabular}{lcccc}
\hline Sources of variation & df & SS & MS & $F$ value \\
\hline Metal oxidation state (MOS) & 1 & 0.23 & 0.23 & $798^{*}$ \\
Metal ions conc. (MC) & 19 & 1.85 & 0.097 & $335^{*}$ \\
MOS $\times$ MC & 19 & 0.07 & 0.004 & $14^{*}$ \\
Error & 80 & 0.02 & 0.002 & 0 \\
Total & 119 & 2.17 & & \\
\hline
\end{tabular}

" significant at $p \leqslant 0.001$. 


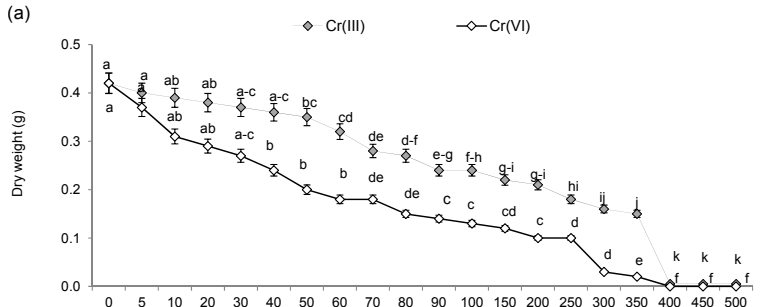

(b)

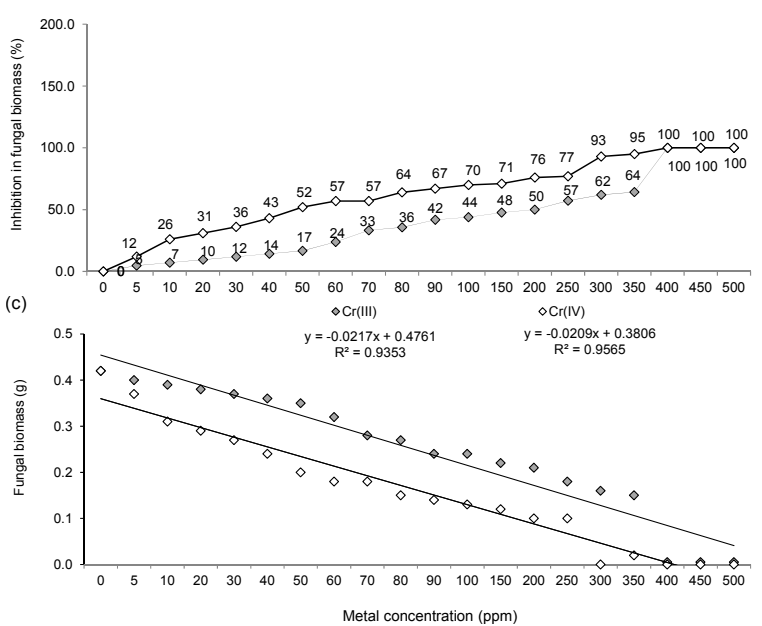

Fig. 1 Growth inhibition of Fusarium oxysporum f. sp. lycopersici due to different concentrations of $\mathrm{Cr}$ (III) and Cr(VI): (a) dry biomass; (b) percentage decrease in biomass over control; (c) regression analysis for the relationship between different concentrations of metal ions and fungal biomass. Vertical bars show standard errors of means of three replicates. Values with different letters at their top show significant difference $(p \leqslant 0.05)$ as determined by Tukey's HSD test.

as well as their different concentrations (MC) was highly significant $(p \leqslant 0.001)$. Similarly, interactive effect of the MOS $\times$ MC was also found to be highly significant $(p \leqslant 0.001)$.

Growth assays against various concentrations of $\mathrm{Cr}(\mathrm{III})$ and $\mathrm{Cr}(\mathrm{VI})$ were calculated in terms of the percentage of growth inhibition, metal accumulation, metal uptake capacity, efficiency, BF, and regression analysis by the biomass of $F$ oxysporum f. sp. lycopersici (Figs. 1-4). Generally, biomass of the fungus exhibited more tendency to accumulate $\mathrm{Cr}(\mathrm{VI})$ than $\mathrm{Cr}(\mathrm{III})$. The fungus hold more capacity, efficiency, and $\mathrm{BF}$ against increasing concentration of $\mathrm{Cr}(\mathrm{VI})$ than that of $\mathrm{Cr}(\mathrm{III})$. Growth and, therefore, biomass were significantly decreased with increased concentrations of either $\mathrm{Cr}(\mathrm{III})$ or $\mathrm{Cr}(\mathrm{VI})$ up to $350 \mathrm{ppm}$, and beyond $400-500 \mathrm{ppm}$ the fungus was unable to grow.

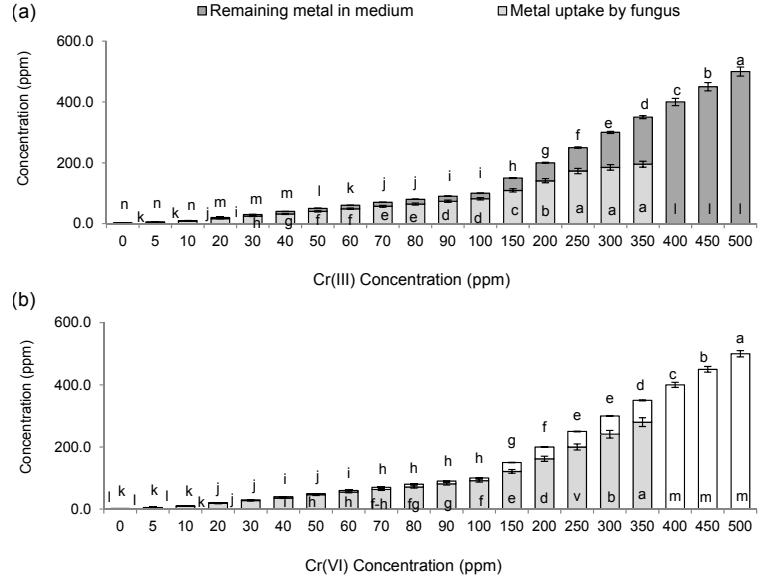

Fig. 2 Metal accumulation by biomass of F. oxysporum f. sp. lycopersici at different concentrations of $\mathrm{Cr}$ (III) and Cr(VI). (a) $\mathrm{Cr}$ (III) accumulation by fungal biomass; (b) $\mathrm{Cr}(\mathrm{VI})$ accumulation by fungal biomass. Vertical bars show standard errors of means of three replicates. Values with different letters at their top show significant difference $(p \leqslant 0.05)$ as determined by Tukey's HSD test.

Under $\mathrm{Cr}(\mathrm{III})$ stress, biomass of $F$ oxysporum f. sp. lycopersici was insignificantly inhibited by $14 \%(0.35 \mathrm{~g})$ at concentration range of $5-40 \mathrm{ppm}$ and significantly decreased by $20-60 \%$ $(0.3-0.15 \mathrm{~g})$ with increase in metal concentration from 50-350 ppm over control (0.42 g) (Fig. 1a and Fig. 1b). At higher concentrations (400, 450, and $500 \mathrm{ppm}$ ) of $\mathrm{Cr}(\mathrm{III})$, however, the fungus was unable to grow, resulting in 100\% growth inhibition. When the growth medium was supplemented with 5-20 ppm of $\mathrm{Cr}(\mathrm{VI})$, the fungal biomass was insignificantly declined by $30 \%$ over the control. However, biomass of the fungus was significantly reduced by $70 \%$ and $95 \%$ over the control with further increase in $\mathrm{Cr}(\mathrm{VI})$ concentration in the range of 30 100 ppm and 150-350 ppm, respectively, while no growth was observed beyond $350 \mathrm{ppm}$ (Fig. 1a and Fig. 1b). Regression analysis $\left(R^{2} \leqslant 0.93\right)$ showed a linear relationship between growth of the fungus and increase in concentrations of each of $\mathrm{Cr}$ (III) and Cr(VI) within the range of 10-500 ppm (Fig. 1c).

Remaining metal concentration (ppm) detected in the growth medium and in the fungal biomass is presented in Fig. 2a and Fig. 2b. The metal accumulation by the fungal biomass was decreased and the remaining amount in growth medium was increased with an increase in metal concentration. There was no precipitation of metal in the growth medium. The fungus accumulated $70-80 \%$ of $\mathrm{Cr}$ (III) at con- 


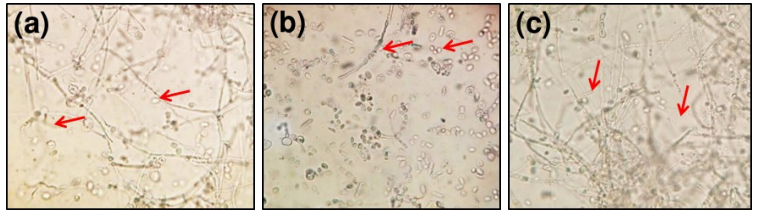

Fig. 3 Microscopic growth characteristics of F. oxysporum f. sp. lycopersici at $40 \times$ due to effect of metal-medium amended with $300 \mathrm{ppm}$ of $\mathrm{Cr}(\mathrm{III})$ and $\mathrm{Cr}(\mathrm{VI})$ solutions: (a) control (macroconidia with hyaline hyphae and normal septation); (b) Cr(III) (shrinking of microconidia along with compartmentalization of hypha); (c) $\mathrm{Cr}(\mathrm{VI})$ (few micro conidia with shrunken hyphae and extensive hyphal branching).

centration range of $10-150 \mathrm{ppm}$ and the rest of metal was detected in the growth medium. At 200 and $250 \mathrm{ppm}$, the fungus accumulated $70 \%$, and at 300 and $350 \mathrm{ppm}$, the fungus accumulated about $66 \% \mathrm{Cr}$ (III) (Fig. 2a). At $300 \mathrm{ppm}$ of Cr(III), F. oxysporum f. sp. lycopersici showed reduction in size of microconidia along with compartmentalization of hypha with few macroconidia (Fig. 3a and Fig. 3b) as compared to the control (Fig. 3a). The fungus held greater tendency to accumulate $\mathrm{Cr}(\mathrm{VI})$ than $\mathrm{Cr}(\mathrm{III})$. Thus metal accumulation was found within a range of $80-90 \%$ due to $\mathrm{Cr}(\mathrm{VI})$ concentration regimes of 5-350 ppm (Fig. 2b). At $300 \mathrm{ppm}$ of $\mathrm{Cr}(\mathrm{VI})$, orange colour of medium changed to slight yellow shade. Microscopic examination showed that the number and the size of microconidia were declined with shrunken and increased hyphal branching, while no macroconidia were observed as compared to the control (Fig. 3a and Fig. 3c). However, with further increase in either $\mathrm{Cr}$ (III) or $\mathrm{Cr}(\mathrm{VI})$ concentration above $350 \mathrm{ppm}, 100 \%$ of the metal was detected in the growth medium.

Results derived from the metal accumulation data were used to calculate fungal metal uptake capacity and efficiency (Fig. 4a and Fig. 4b). Fungal biomass exhibited the greater accumulation capacity $(0.01-2.6 \mathrm{mg} / \mathrm{g})$ for $\mathrm{Cr}(\mathrm{VI})$ than that of Cr(III) (0.01-1.86 mg/g). Likewise, metal uptake efficiency was greater (80-90\%) due to the effect of various concentrations of $\mathrm{Cr}(\mathrm{VI})$ than that of $\mathrm{Cr}$ (III) (70-80\%). The fungus exhibited good BF at lower concentrations of metal as compared to higher doses, therefore it could be classified as moderately tolerant to $\mathrm{Cr}$ stress. $\mathrm{BF}$ of the fungus was 0.90 due to $\mathrm{Cr}(\mathrm{VI})$ concentrations of up to $100 \mathrm{ppm}$, and 0.81 up to concentrations of $350 \mathrm{ppm}$. On the other hand, BF of the fungus was 0.8 up to $100 \mathrm{ppm}$ and

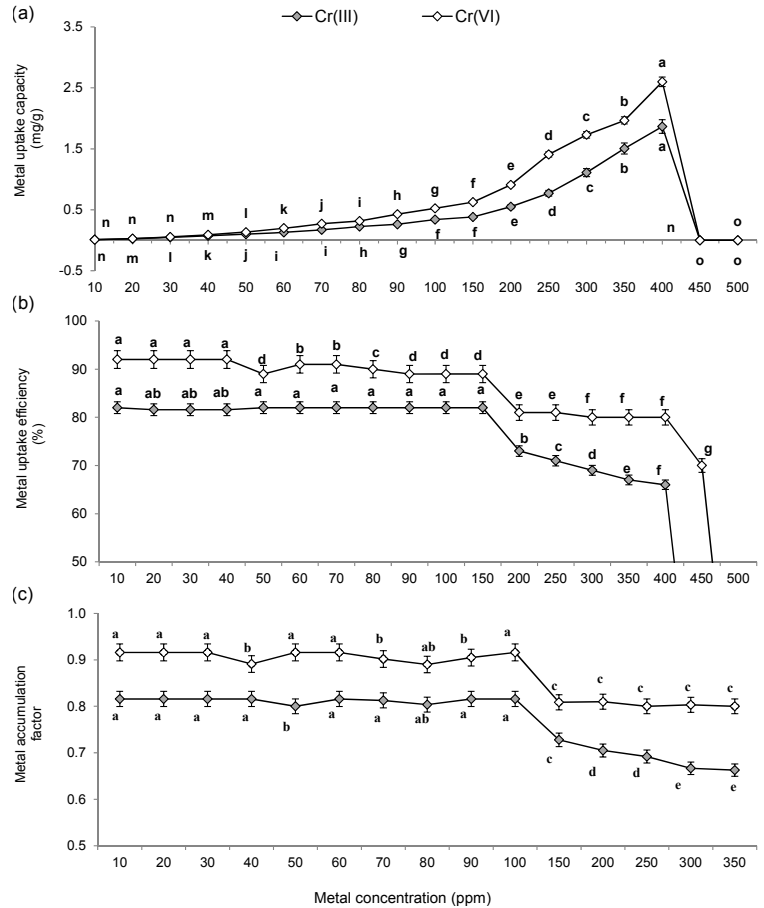

Fig. 4 Influence of $\mathrm{Cr}$ (III) and $\mathrm{Cr}(\mathrm{VI})$ on (a) metal uptake capacity, (b) uptake efficiency, and (c) BF of F. oxysporum f. sp. lycopersici. Vertical bars show standard errors of means of three replicates. Values with different letters at their top show significant difference $(p \leqslant 0.05)$ as determined by Tukey's HSD test.

0.7 up to $350 \mathrm{ppm}$ of the $\mathrm{Cr}(\mathrm{III})$ (Fig. 4c).

\section{DISCUSSION}

It was found that $F$ oxysporum f. sp. lycopersici is sensitive to both $\mathrm{Cr}(\mathrm{III})$ and $\mathrm{Cr}(\mathrm{VI})$, thus exhibited high accumulation of total $\mathrm{Cr}$ at low concentration with reduction in growth ${ }^{25}$. Reduction in growth of $F$. oxysporum f. sp. lycopersici with increase in Cr concentration within the range of 5-350 ppm and then absence of growth at metal concentration $>350 \mathrm{ppm}$ could be due to the toxic effect of the metal $^{26}$. Low concentrations of $\mathrm{Cr}(\mathrm{III})$ or $\mathrm{Cr}(\mathrm{VI})$ were stimulatory for the growth of $F$ oxysporum $\mathrm{f}$. sp. lycopersici and vice versa with increase in the metal concentration ${ }^{27}$. The reduction in growth of fungus and change in microscopic features of the fungus at higher metal concentrations could be attributed to internalization of metals in the cytosol, where it probably disrupts cell integrity and cell functions (e.g. mitochondrial electron transport chain, glycolysis, and oxidative phosphorylation) and cause growth retardation ${ }^{28}$. Besides, loops 
and connective filament development together with an increase of hyphal branching indicate an increasing concentration of the metal in fungus ${ }^{29}$. Moreover, metal displacing essential metal with the contaminant metal and mutation of biomolecule consequences in failure of fungus to perform normal activities. Whereas, no growth of fungus at the highest range of metal concentrations possibly occurs owing to non-sporulation of $F$. oxysporum $\mathrm{f}$. sp. lycopersici mycelium under extreme toxicity level or prolongation of lag phase.

The greater toxicity of $\mathrm{Cr}(\mathrm{VI})$ compared with $\mathrm{Cr}$ (III) may result from its more mobile ability; usually, $\mathrm{Cr}(\mathrm{VI})$ can get into the cells of the fungus more easily and cause oxidative damage during its reduction ${ }^{30}$. It could be due to the fact that microorganisms require $\mathrm{Cr}(\mathrm{III})$ in minute amounts. So this trivalent form probably incorporates into the fungus whereas no machinery is available for hydrolysis of $\mathrm{Cr}(\mathrm{VI})$, hence incorporation of hexavalent $\mathrm{Cr}$ directs all the resources towards initialization of defence response in fungi and lesser energy is left for growth. Further $\mathrm{Cr}(\mathrm{VI})$ toxicity was reported to link with its specific antagonism to sulphate uptake, whereas $\mathrm{Cr}$ (III) toxicity resulted from antagonism with iron transport $^{31}$.

It was noticed that fungus exhibited $90 \%$ efficiency to uptake $\mathrm{Cr}(\mathrm{VI})$ at concentration range of 5-100 ppm, while efficiency declined by $12 \%$ at the range of $150-350 \mathrm{ppm}$. The fungus was able to uptake $80 \%$ of the $\operatorname{Cr}(\mathrm{III})$ at $5-100 \mathrm{ppm}$, and approximately $70 \%$ within the range of 100 $350 \mathrm{ppm}$. However, at the remaining concentrations of 350,400 , and $500 \mathrm{ppm}$ of both $\mathrm{Cr}(\mathrm{III})$ or $\mathrm{Cr}(\mathrm{VI})$, $100 \%$ of the metal was detected in the growth medium with no growth of the fungus. Effluent loaded with noxious organic compounds was found hinder the fungus growth and enhance heavy metal uptake $^{32}$. In another study ${ }^{26}, 90 \%$ of the $\mathrm{Cr}(\mathrm{VI})$ was found to be accumulated by $F$ oxysporum at $100-200 \mathrm{ppm}, 80 \%$ for $300-400 \mathrm{ppm}$, and up to $65 \%$ for $500-1000 \mathrm{ppm}$. Likewise, $100 \%$ removal of $\mathrm{Cr}(\mathrm{VI})$ by different soil fungi including Fusarium sp. was recorded ${ }^{33}$. Greater metal accumulation at low metal concentration might be due to the presence of essential energy metabolism and energy coupled transport system similar to metallothionein function ${ }^{34}$. However, at low metal concentration fungus could detoxify metal by complexing it with phosphate analogues, carboxyl groups or histidine analogues ${ }^{35}$. There is also a possibility of increased melanin production in the growth medium amended with $\mathrm{Cr}$ that may in turn increase the metal binding ability of the fungus. Besides, reduction in metal accumulation capacity of the fungus with increase in either Cr(III) or (VI) concentrations might be owing to saturation of the fungus metal-binding sites ${ }^{36}$. At low metal concentrations (5-100 ppm), there could be more binding sites for complexion of chromium with fungal biomass. However, at higher metal concentrations $(>100)$, toxicity of metal was likely to reduce fungal biomass, increase competition for less binding sites and therefore resulted in low metal uptake efficiency by the fungus ${ }^{37}$.

Growth medium supplemented with $\mathrm{Cr}(\mathrm{VI})$ caused change in colour of medium from orangeyellow to its lighter shade with the advent of incubation time. The maximum discolouration was observed at the 15th day of incubation. No alteration in colour was observed in case of $\mathrm{Cr}$ (III)-amended medium. Besides, no change in colour of the growth medium was noticed at concentrations above 300$350 \mathrm{ppm}$ where the fungus was unable to grow. The fungus likely to utilize carbon source in the growth medium as one of the efficient electron donors to reduce $\mathrm{Cr}(\mathrm{VI})$ and was accompanied by a change in colour of the medium ${ }^{25}$.

The BF represents the pollutant concentration in fungus comparing with the environment concentration $^{38}$. A value of $\mathrm{BF}$ greater than 1 is considered to be an efficient tool in the polluted soil bioremediation. Presently, BF of the fungus (BF: 0.7-0.9) was comparatively better at low concentrations ( $>300 \mathrm{ppm}$ ), therefore the fungus could be ranked as moderately tolerant to $\mathrm{Cr}$ stress.

\section{CONCLUSIONS}

F. oxysporum f. sp. lycopersici is moderately tolerant to both $\mathrm{Cr}(\mathrm{III})$ and $\mathrm{Cr}(\mathrm{VI})$. Increase in metal concentration within the range of 5-350 ppm resulted in gradual reduction in fungal growth and the fungus was unable to grow at $400-500 \mathrm{ppm}$. The pathogenic fungus accumulated more metal at lower than at higher concentrations. Furthermore, the fungus exhibited more tendency to accumulate $\mathrm{Cr}(\mathrm{VI})$ than $\mathrm{Cr}(\mathrm{III})$.

Acknowledgements: Authors are thankful to University of the Punjab, Lahore, Pakistan for providing funding to complete current research work.

\section{REFERENCES}

1. Barceloux DG (1999) Chromium. J Toxicol Clin Toxicol 37, 173-94.

2. Caglieri A, Goldoni M, Acampa O, Andreoli R, Vettori MV, Corradi M, Apostoli PA, Mutti A (2006) The effect 
of inhaled chromium on different exhaled breath condensate biomarkers among chrome-plating workers. Environ Health Perspect 114, 542-6.

3. Smith WA, Apel WA, Petersen JN, Peyton BM (2002) Effect of carbon and energy source on bacterial chromate reduction. Bioremediat $J$ 6, 205-15.

4. Shrivastava R, Upreti RK, Seth PK, Chaturvedi UC (2002) Effects of chromium on the immune system. FEMS Immunol Med Microbiol 34, 1-7.

5. Sharma DC, Sharma CP, Tripathi RD (2003) Phytotoxic lesions of chromium in maize. Chemosphere 51, 63-8.

6. Marchese M, Gagneten AM, Parma MJ, Pavé PJ (2008) Accumulation and elimination of chromium by freshwater species exposed to spiked sediments. Arch Environ Contam Toxicol 55, 603-9.

7. Cárdenas-González JF, Acosta-Rodríguez I (2010) Hexavalent chromium removal by a Paecilomyces sp. fungal strain isolated from environment. Bioinorg Chem Appl 2010, Article ID 676243.

8. Shewry PR, Peterson JP (1974) The uptake of chromium by barley seedlings (Hordeum vulgare L.). $J$ Exp Bot 25, 785-97.

9. Ellis RJ, Neish B, Trett MW, Best JG, Weightman AJ, Morgan P, Fry JC (2001) Comparison of microbial and meiofaunal community analyses for determining impact of heavy metal contamination. $J$ Microbiol Meth 45, 171-85.

10. Lugauskas A, Levinskaitè L, Pečiulytė D, Repečkienè J, Motuzas A, Vaisvalavičius R, Prosyčevas I (2005) Effect of copper, zinc and lead acetates on microorganisms in soil. Ekologija 2005, 61-9.

11. Gadd GM (1993) Interaction of fungi with toxic metals. New Phytol 124, 25-60.

12. Shoaib A, Naureen A, Tanveer F, Aslam N (2012) Removal of $\mathrm{Ni}(\mathrm{II})$ ions from substrate using filamentous fungi. Int J Agr Biol 14, 831-4.

13. Bellion M, Courbot M, Jacob C, Guinet F, Blaudez D, Chalot M (2007) Metal induction of a Paxillus involutus metallothionein and its heterologous expression in Hebeloma cylindrosporum. New Phytol 174, 151-8.

14. Cánovas D, Vooijs R, Schat H, de Lorenzo V (2004) The role of thiol species in the hypertolerance of Aspergillus sp. P37 to arsenic. J Biol Chem 279, 51234-40.

15. Zetić VG, Tomas VS, Grba S, Lutilsky L, Kozlek D (2001) Chromium uptake by Saccharomyces cerevisiae and isolation of glucose tolerance factor from yeast biomass. $J$ Biosci 26, 217-23.

16. Bhattacharyya S, Pal TK, Basumajumdar A (2009) Effect of some complex nutrients on improvement of bioaccumulation of lead by Rhizopus arrhizus. $J$ Indian Chem Soc 86, 749-52.

17. Houterman PM, Speijer D, Dekker H, Koster CG, Cornelissen BJ, Rep M (2007) The mixed xylem sap proteome of Fusarium oxysporum infected tomato plants. Mol Plant Pathol 8, 215-21.
18. Abdel-Monaim MF (2012) Induced systemic resistance in tomato plants against Fusarium wilt diseases. Int Res J Microbiol 3, 14-23.

19. Maharshi AR, Thaker VS (2012) Growth and development of plant pathogenic fungi in define media. Eur J Exp Biol 2, 44-54.

20. Olivain C, Trouvelot S, Binet M, Cordier C, Pugin A, Alabouvette C (2003) Colonization of flax roots and early physiological responses of flax cells inoculated with pathogenic and non-pathogenic strains of Fusarium oxysporum. Appl Environ Microbiol 69, 5453-62.

21. Idris AE, Abouzeid MA, Boari A, Vurro M, Evidente A (2003) Identification of phytotoxic metabolites of a new Fusarium sp. inhibiting germination of Striga hermonthica seeds. Phytopathol Mediterr 42, 65-70.

22. Agrios GN (2006) Plant Pathology, 5th edn, Academic Press, San Diego, CA.

23. Corrales Escobosa AR, Wrobel K, Landero Figueroa JA, Gutiérrez Corona JF, Wrobel K (2010) Effect of Fusarium oxysporum f. sp. lycopersici on the soil-toroot translocation of heavy metals in tomato plants susceptible and resistant to the fungus. J Agr Food Chem 58, 12392-8.

24. Maneva S, Vatchev T, Miteva E (2013) Effect of lead excess in soil on the accumulation of $\mathrm{P}, \mathrm{K}$ and $\mathrm{Na}$ in infected by Fusarium oxysporum f. sp. radicislycopersici in tomato (Lycopersicon esculentum Mill.) plants. Bulg J Agr Sci 19, 972-80.

25. Cervantes C, Campos-García J, Devars S, GutiérrezCorona F, Loza-Tavera H, Torres-Guzmán JC, Moreno-Sánchez R (2001) Interactions of chromium with microorganisms and plants. FEMS Microbiol Rev 25, 335-47.

26. Amatussalam A, Abubacker MN, Rajendran RB (2011) In situ Carica papaya stem matrix and Fusarium oxysporum (NCBT-156) mediated bioremediation of chromium. Indian J Exp Biol 49, 925-31.

27. Naguib MI, Haikal NZ, Gouda S (1984) Effect of chromium ions on the growth of Fusarium oxysporum f. sp. lycopersici and Cunninghamella echinulata. Arab Gulf J Sci Res 2, 149-57.

28. Capobianco JO, Zakula D, Frost DJ, Goldman RC, Li L, Klein LL, Lartey PA (1998) Cellular accumulation, localization and activity of a synthetic cyclopeptamine in fungi. Antimicrob Agents Chemother 42, 389-93.

29. Lilly WW, Wallweber GJ, Lukefahr TA (1992) Cadmium absorption and its effects on growth and mycelial morphology of the basidiomycete fungus, Schizophyllum commune. Microbios 72, 227-37.

30. Murugesan AG, Maheswari S (2007) Uptake of hexavalent chromium from aqueous solution employing live, dead and immobilized bacterial biomass. J Appl Sci Environ Manag 11, 71-5.

31. Ramana VV, Sastry KS (1994) Chromium toxicity in Neurospora crassa. J Inorg Biochem 56, 87-95.

32. Rajapaksha RMCP, Tobor-Kapłon MA, Bååth E (2004) 
Metal toxicity affects fungal and bacterial activities in soil differently. Appl Environ Microbiol 70, 2966-73.

33. Seshikala D, Singara Charya MA (2012) Effect of $\mathrm{pH}$ on chromium biosorption. Int $J$ Pharm Biol Sci 2, 298-302.

34. Magyarosy A, Laidlaw RD, Kilaas R, Echer C, Clark DS, Keasling JD (2002) Nickel accumulation and nickel oxalate precipitation by Aspergillus niger. Appl Microbiol Biotechnol 59, 382-8.

35. Wu S, Zhang X, Sun Y, Wu Z, Li T, Hu Y, Su D, Lv $\mathrm{J}$, et al (2015) Transformation and immobilization of chromium by arbuscular mycorrhizal fungi as revealed by SEM-EDS, TEM-EDS, and XAFS. Environ Sci Tech 49, 14036-47.

36. Srinivasa Rao P, Kalyani S, Suresh Reddy KVN, Krishnaiah A (2005) Comparison of biosorption of nickel (II) and copper (II) ions from aqueous solution by Sphaeroplea algae and acid treated Sphaeroplea algae. Separ Sci Tech 40, 3149-65.

37. Kumar RR, Lee JT, Cho JY (2012) Toxic cadmium ions removal by isolated fungal strain from e-waste recycling facility. $J$ Environ Appl Biores 1, 1-4.

38. Scragg A (2005) Environmental Biotechnology, Oxford Univ Press, New York. 